\title{
Sit Back or Dig In: The Role of Activity Level in Landscape Market Segmentation
}

\author{
Melinda Knuth \\ Department of Horticultural Sciences, Texas A\&M University, 2133 TAMU, \\ College Station, TX 77843
}

Bridget K. Behe

Department of Horticulture, Michigan State University, 1066 Bogue Street, East Lansing, MI 48824-1325

\author{
Charles R. Hall \\ Department of Horticultural Sciences, Texas A\&M University, 2133 TAMU, \\ College Station, TX 77843
}

Patricia T. Huddleston

Department of Advertising and Public Relations, Michigan State University, 404 Wilson Road, East Lansing, MI 48824

\section{R. Thomas Fernandez \\ Department of Horticulture, Michigan State University, 1066 Bogue Street, East Lansing, MI 48824-1325}

Additional index words. consumer, landscape, online survey, purchase

\begin{abstract}
Activity level, or the amount of action/interaction with a product, can be an indication of interest in a product category and influences purchases. Our goal was to assess the overall market for landscape plants using consumers' activity level from the active/ passive continuum proposed by Pine and Gilmore (2011). An online survey instrument was administered to invitees from a national online panel from 7 to 13 Sept. 2016 yielding 1543 useful responses. Factor analysis of 23 items adapted from a previous study revealed five factors, including one active factor and a separate passive factor. These two factors were used in the present study as a basis for a k-means cluster analysis. Two clusters emerged and were labeled "Active Engagement" and "Obligatory Passive Engagement" in landscape activities. We compared cluster means for all five factors and found the Active cluster purchased more plants of all types as well as had greater landscape pride and desire for a low (water) input landscape. Members of the Active cluster were from higher income and education households which were slightly larger and more likely to have Caucasian residents compared with the Passive cluster. In practice, retail employees and landscape professionals might initially ask about consumers' activity level desired in the landscape as a screening question. Subsequent assistance in design and/or plant selection/purchase could then be tailored toward the desired activity level.
\end{abstract}

Markets are rarely homogeneous, and market segmentation can be a viable means of efficiently and profitably reaching different consumer groups. This is true for many products,

Received for publication 22 Apr. 2019. Accepted for publication 16 July 2019.

Funding for this study was provided by U.S. Department of Agriculture (USDA) Specialty Crop Research Initiative Clean Wate ${ }^{3}$ - Reduce, Remediate, Recycle Grant Number 2014-51181-22372; USDA National Institute of Food and Agriculture Hatch Projects MICL 02589 and 02473, and TEX0-1-7051; Michigan State University (MSU) AgBioResearch and MSU Project GREEN; and Texas A\&M AgriLife Research.

M.K. is a Doctoral student.

B.K.B. is a Professor.

C.R.H. is a Professor and Ellison chair.

P.T.H. is a Professor.

R.T.F. is a Professor

B.K.B. is the corresponding author. E-mail: behe@ msu.edu. become stagnant or declined. A maturing market is more competitive. Intensified competition potentially changes how marketers communicate with their customers because firms strive to combat heightened competition and margin reductions (Abell, 2010). Heightened competition also may influence how marketers communicate with customers.

Activity level, or the amount of action and/or interaction, influences what people buy (Pine and Gilmore, 2011), how people use and enjoy residential landscapes, and how marketers communicate with them. Both active participation and passive enjoyment may be derived from landscaping and a landscaped environment. Active participation might be in the form of planting or weeding, whereas passive enjoyment may occur as entertaining friends or reading in a beautiful setting. Yet, the activity type and level in which consumers engage with residential landscapes has not been well investigated. Our objective was to explore the role of consumers' type and activity level, as described in Pine and Gilmore (2011) and further elaborated by Hall and Dickson (2011), on landscape purchases to determine a market segmentation that might be a practical basis for targeting consumers.

Approximately $75 \%$ of Americans live in urban areas where an estimated $41 \%$ of the land area is residential; half of which is primarily vegetation (Mathieu et al., 2007; Nowak et al., 1996). The amount of residential area used for yard or landscape depends on socioeconomic characteristics, housing density, and property size (Daniels and Kirkpatrick, 2006; Kirkpatrick et al., 2007; Lin et al., 2017; Loram et al., 2008; Marco et al., 2008). Newer suburban developments have larger houses and smaller backyards than older communities (Hall, 2010). Attitudes (Clayton, 2007) and demographic characteristics influence landscape perceptions (Blaine et al., 2012; Boone et al., 2010; Chau et al., 2010; Clayton, 2007; Kirkpatrick et al., 2012; Mennis, 2006), but activities other than purchases (Behe et al., 2010, 2013, 2016; Cohen and Baldwin, 2018) have not been well described. We propose that activity type and level also may play a role in landscape purchases and enjoyment.

\section{Activity Type and Level}

How individuals engage in and derive enjoyment from processes and products potentially influences their activity level and purchases. Pine and Gilmore (2011) described a theoretical framework for marketing experiences in two dimensions: activity/ passivity and absorption/immersion. The two dimensions combined create four quadrants (Fig. 1). Actively immersed experiences were classified as escapist experiences, whereas passively immersed experiences were classified as aesthetic experiences in which a person has little to no effect on the environment but rather 
views or enjoys the scene. Actively absorptive experiences were labeled educational, whereas passively absorbing experiences were considered entertainment. The active/passive and absorption/immersion dimensions are relevant in light of the benefits consumers derive from horticultural products, services, and experiences. In a comprehensive review of plant benefits, Hall and Dickson (2011) summarized the economic, environmental, and health and well-being benefit research involving plants. Both active and passive plant interactions facilitated human health and well-being. For example, learning, healing, memory, and concentration were all improved from passive interactions with plants. In addition, active plant interactions, such as growing or nurturing plants, improved a person's psychological state. Yet, little research has investigated the activepassive motivation for interacting with plants and the impact it has on plant purchases.

Syme et al. (2004) identified five factors whereby consumers related to the residential landscape: lifestyle, garden recreation, garden interest, conservation attitude, and social desirability. Of these, garden recreation was related to an active experience and included items like "I enjoy showing friends around the garden." Knuth et al. (2018) adapted the residential experience factors from Syme et al. (2004). From the principal component analysis of Knuth et al. (2018), an active experience factor as well as a separate passive experience factor emerged. A greater understanding of the influence of active and passive experiences on perceptions of plantrelated factors, plant buying habits, and sociodemographic characteristics can add another dimension for marketers to potentially connect with American consumers through merchandising and messaging.

\section{Attitudinal Influences}

Some research suggests the most essential services provided by residential landscapes are cultural, as they promote human mental and physical well-being and are places for recreation and gathering with family and friends (Abraham et al., 2010; Beard and Green, 1994; Matsuoka and Kaplan, 2008). Indeed, residents reported a sense of comfort in their yards and a "sense of place" as well as greater neighborhood satisfaction and

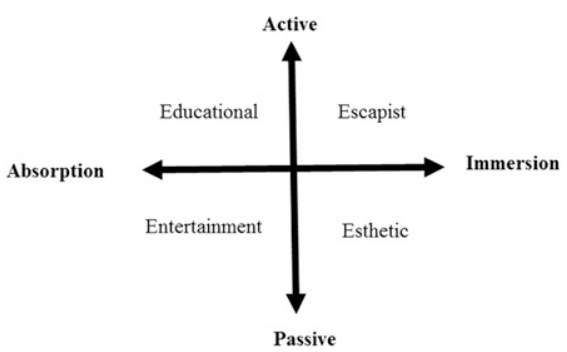

Fig. 1. Theoretical framework for experience types, shown in each quadrant, derived from engaging with products in two dimensions: active/ passive and absorption/immersion, as posited by Pine and Gilmore (2011). social interactions when surrounded by more open space and trees (Crow et al., 2006; Kweon et al., 2010; Larsen and Harlan, 2006). Outdoor space is often considered a functional extension of the home, designed and managed to meet aesthetic and recreational preferences (Bhatti and Church, 2001; Larsen and Harlan, 2006). These spaces can accommodate both active and passive experiences that may be considered either immersion or aesthetic experiences on the Pine and Gilmore (2011) continuum.

However, not all homeowners have positive associations with their landscape. Harris et al. (2013) defined a landscape "reformer" as someone who reduced their lawn by diversifying landscape plants but had limited success due to lack of time, knowledge, or money. These participants had mixed feelings about their landscape or had a negative experience. Some homeowners had negative attitudes associated with landscape activities. Negative feelings about landscaping may arise from lack of compliance with homeowners association (HOA) regulations because of opposing or alternative landscape ideals resulting in dissatisfaction (Robbins et al., 2001). Blaine et al. (2012) found a positive association with the importance of institutionalized landscape aesthetics through the HOA and a barrier to creativity and innovation indicating that social pressure (through neighbors' actions or HOA requirements) determines landscape aesthetics rather than the homeowner's personal wants. Negative attitudes may influence activity and purchases.

Some of the negativity toward landscape activities may arise when a landscape differs from conventional norms. In the MetroDetroit area, Nassauer et al. (2009) showed the neighbor's yard strongly influenced a participant's preference for their own front yard with participants striving to conform, indicating the power of neighborhood norms. Undergraduate students expressed a preference for "clean and neat" "natural and wild" landscapes, the former of which conform better to social norms compared with the latter (Zheng et al., 2011). Beck et al. (2002) showed 34 Master Gardener conventional ornamental landscapes and edible landscapes in an identical format. The participants reported the ornamental landscape was more easily managed compared with the less conventional edible landscape. These studies point to a positive feeling arising from what may be perceived as typical or conventional landscaping or landscapes, consistent with existing norms or expectations of a residential landscape.

Residents who were highly involved in their landscape felt more closely linked to naturalism and valued their privacy, wildlife, aesthetics, and recreation (Nelson et al., 2005). Harris et al. (2013) took this identity a step further by defining landscape participation into three different categories: diversifier, lawn maintainer, and reformer. A diversifier, as compared with the reformers and lawn maintainers, had the knowledge and confidence to create landscapes with edible, nonedible, and ornamental plants. These landscape participants had time, money, or both, to invest in their landscape for enjoyment purposes and had positive feelings related to their landscape, such as pride, joy, satisfaction, and relaxation (Harris et al., 2013). A diversifier had the strongest relationship to involvement. In these three landscape categories, one can identify potential variance in activity level and type of experience.

Our objective was to explore the relationship between consumers' type and activity level with residential landscapes to determine whether an actionable market segmentation might result. We hypothesized that activity level (active to passive) may create the basis for a practical market segmentation based on the active/passive dimension from Pine and Gilmore (2011). We also hypothesized that consumers' purchasing behavior and demographic background also would be heterogeneous.

\section{Materials and Methods}

An online survey instrument was administered from 7 to 13 Sept. 2016 using widely accepted market research protocols to ensure a high degree of accuracy and data collection speed, while reducing human error and survey expenses (Cobanoglu et al., 2001; Dillman et al., 2009; McCullough, 1998). The content and formatting of the survey questions were adapted from Syme et al. (2004) and Behe et al. (2013, 2015). The use of online surveys can have disadvantages, especially if the sampling database contains the same panelist under different accounts, although most professional panels strive to develop representative samples for their clients. We contracted with Lightspeed GMI (Warren, $\mathrm{NJ}$ ) which maintains a panel of $\approx 1.3$ million persons and has control mechanisms in place to eliminate duplicate panelists. They identified a random sample of individuals 18 years of age or older and who had bought a plant within 2016 (the year the survey was administered). Subjects were directed to answer four quality assurance checkpoints in a specific manner after consenting to participate in the study (Zhu et al., 2017). This was to ensure respondents were reading every question. Both the instrument and protocol were approved by the University Committee on Research Involving Human Subjects (IRB\# x16-1053e Category: Exempt 2).

As Knuth et al. (2018) did, we conducted a principal component analysis on 23 items adapted from Syme et al. (2004), from which five factors related to landscape and plant importance emerged. We selected two factors to reflect the active/passive dimension proposed in Pine and Gilmore (2011). We conducted an agglomerative cluster analysis in SPSS (Version 25; Chicago, IL) $k$-means clustering procedure, saving cluster membership for comparisons and mean testing using the demographic characteristics and the other components identified in the 
prior analyses. A $k$-means cluster analysis was chosen over hierarchical cluster due to past literature indicating $k$-means to be more appropriate for consumer preference studies (Lawless and Heymann, 2010).

We then conducted an analysis of variance to quantify differences in all five factors and compared cluster means on demographic characteristics, and plantrelated expenditures from eight categories: annuals, perennials, herb transplants, vegetable transplants, flowering shrubs, evergreen shrubs, fruiting trees, flowering trees, and evergreen trees.

\section{Results and Discussion}

The mean age of respondents was 40 years ( \pm 16.9 years) and respondents were predominately female $(57.8 \%)$. The mean household size was 1.2 adults and had a mean of 0.43 children for a mean household size of $\approx 2$ persons. Respondents were primarily Caucasian (90\%), followed by Black/African American $(4 \%)$, Hispanic $(3 \%)$, Asian $(2 \%)$, and Native American, Pacific Islander, and other races (1\%). Approximately a third $(28.3 \%)$ had earned a 4-year college degree followed by $21 \%$ of respondents who had some college. More than half of the respondents lived in suburban areas (59.8\%) and mean 2015 household income was $\$ 60,000$ to $\$ 79,999$.

Demographically, the present study was similar to the 2016 U.S. Population Census (U.S. Census Bureau, 2017) in which mean household income from 2010 to 2015 was $\$ 79,263$. The total U.S. population was $\approx 323$ million, with an average household size of 2.6 persons. The population was $77 \%$ Caucasian, 13.3\% Black/African American, $17.6 \%$ Hispanic, $5.6 \%$ Asian, and $1.4 \%$ Native American, Pacific Islander, or other races. Nationally, $29.8 \%$ of U.S. citizens had earned a bachelor's degree or higher. Female individuals represented $50.8 \%$ of the population and the median age was 37.9 years (U.S. Census Bureau, 2017). Without published variances of the census information, it was not possible to test for statistical differences between the samples.

The principal component factor analysis of 23 items relating to horticultural importance adapted from Syme et al. (2004) produced a five-component solution with a Cronbach's alpha $=0.8571$ and accounted for $67.1 \%$ of the variance in the items (Table 1), identical to Knuth et al. (2018). The first component to emerge was Landscape Pride, which contained items with responses to "How important is each of the following to the preferred lifestyle of you and your family," including "a lush landscape," "a landscape that is the envy of the neighbors," "a well-irrigated landscape," "large areas of lawn at your property," "a vibrant landscape," "a landscape that adds value to my home," "large areas of garden beds at your property," and "a landscape that is into the neighborhood." All of the items in the Landscape Pride component were related to landscape beautification and maintenance.
The second component to emerge was identified as Active Landscape Use and Enjoyment and contained six items: "working with plants outdoors is a valuable way to spend time," "working with plants outdoors is a pleasant break from my other activities," "I get great satisfaction from working in the outdoor landscaped areas around my home," "I like to enjoy the harvest from my outdoor vegetables and herbs," "I like to enjoy the look and feel of a nicely landscaped outdoor area," and "I do not like working with outdoor plants." All of the items in Active Landscape Use and Enjoyment were related to positive, active landscape experiences.

The third component to emerge was called Passive Landscape Use and No Enjoyment and contained four items: "I hardly ever use the outdoor space at my home for recreation," "I never entertain friends outdoors," "the outdoor space around my home is an important place for my leisure activities" (negatively), and "my family makes a lot of use of the outdoor space at our home" (negatively). All of the items in Passive Use with No Landscape Use and Enjoyment were related to negative views and passive experiences with landscape use.

The fourth component to emerge contained three items and was labeled Low Maintenance Landscape Desire. This component contained "a landscape with low maintenance," "a landscape that uses no supplemental irrigation," and "a landscape that uses plants with low water requirements." All of the items in Low Maintenance Landscape Desire were related to low effort or low input in landscape maintenance.

The fifth factor to emerge was labeled Response in Drought and contained two items: "in a water crisis, we should not buy or try to maintain outdoor landscape plants" and "I have decreased my outdoor plant purchases due to water restrictions in my neighborhood."

We selected the "Active Landscape Use and Enjoyment" factor and the "Passive Landscape Use and No Enjoyment" factor as the basis for a k-means cluster analysis because they most closely reflected the one active/passive dimension in Pine and Gilmore (2011). Two clusters emerged: one was labeled Active Engagement in Landscape Activities, or Active cluster, and the other was labeled Obligatory Passive Engagement in Landscape Activities, or Passive cluster. We compared cluster means for the five factors (Table 2). Mean factor scores for all of the factors were numerically opposite and significantly different except the Response in Drought factor. Cluster means for four of the five factors for the Active Landscape Use and Enjoyment members and Passive Landscape Use and Enjoyment members were numerically opposite and significantly different. The Active Engagement cluster members had greater Active Landscape Use and Enjoyment, Landscape Pride, and Low Water Input landscape. The Obligatory Passive cluster had greater Passive Landscape Use and Enjoyment. There was no difference between the clusters in terms of their Response in Drought.

The clusters differed in terms of their purchases (Table 3). Members of the Active cluster spent 2.5 times as much on plantrelated products in 2016 and 2015 compared with the Passive cluster. Those in the Active cluster had a higher percentage of participants who bought all the listed types of plants. More than $80 \%$ of the members of the Active cluster purchased annual plants in 2016 compared with $19 \%$ of the members of the Passive cluster. For vegetable transplants, $87.7 \%$ of the Active cluster purchased transplants, whereas only $9 \%$ of the Passive cluster did. More than $80 \%$ of the Active cluster bought herbs compared with $17 \%$ of the Passive cluster.

The Active cluster appreciated more landscape biodiversity like "diversifiers" in Harris et al. (2013). Urban biodiversity through gardens and landscapes can provide ecosystem resilience and other services for better environmental health (Colding, 2007; Dennis and James, 2016; Elmsqvist et al., 2004; Goddard et al., 2010, 2013). The Passive cluster behaves similarly to "reformers," whereby they like the idea of diversity but they may lack time, money, or knowledge. They may have had a negative landscape experience. Therefore, they do not buy as diverse categories of plants as the Active cluster.

Demographically, the clusters differed (Table 4). Participants classified in the Active cluster had a slightly larger household size, with 1.24 adults (vs. 1.09 in the Passive cluster) and 0.59 children (vs. 0.17). Members of the Active cluster also had a higher mean income level compared with members of the Passive cluster ( $\$ 72,470$ vs. $\$ 59,236$ ). There was a higher percentage of Caucasians in the Active cluster compared with members of the Passive cluster. Members of the Active cluster were $37 \%$ female, whereas only $20 \%$ of the members of the Passive cluster were female. Members of the Active Engagement cluster were 5 years younger ( 55 vs. 65) compared with the Passive cluster. The difference in demographic characteristics is in contrast with prior literature (Behe et al., 2018; Cohen and Baldwin, 2018). To extrapolate this to represent the U.S. population, one could say that of plant purchasers, 33 million are women who actively enjoy landscape activities. Of these women, nearly 27 million bought annual plants in 2016 and 30 million of them bought fruit-bearing trees. Because people in the Active cluster were younger, more affluent, and willing to spend more in all segments of plant products, we suggest that they could represent a changing perspective of younger horticulture participants.

\section{Conclusions}

Because markets are rarely homogeneous, market segmentation can be a viable means of efficiently and profitably reaching different market groups. Our objective was 
Table 1. Principal component analysis of 23 items with oblique rotation (Promax) with loadings of 27 initial items relating to landscape and plant importance adapted from Syme et al. (2004). Five components emerged based on the 27 item loadings. Items were removed from the analysis if they loaded 0.500 or less with all components. ${ }^{z}$ The five components that emerged were Beautiful Landscape, Active Landscape Enjoyment, Passive Landscape Enjoyment, Low Maintenance Landscape Desire, and Response in Drought. A UNIVARIATE Procedure was conducted using SAS software. ${ }^{y}$

\begin{tabular}{|c|c|c|c|c|c|}
\hline Item & $\begin{array}{l}\text { Landscape } \\
\text { Pride }\end{array}$ & $\begin{array}{l}\text { Active Landscape Use } \\
\text { and Enjoyment }\end{array}$ & $\begin{array}{l}\text { Passive Landscape Use } \\
\text { and No Enjoyment }\end{array}$ & $\begin{array}{l}\text { Low Maintenance } \\
\text { Landscape Desire }\end{array}$ & $\begin{array}{l}\text { Response in } \\
\text { Drought }\end{array}$ \\
\hline A lush landscape & 0.8431 & 0.0286 & 0.0058 & -0.0700 & -0.0326 \\
\hline A landscape that is the envy of the neighbors & 0.8118 & -0.0098 & 0.0961 & -0.0378 & 0.0307 \\
\hline A well-irrigated landscape & 0.7929 & -0.0425 & 0.0282 & 0.0377 & 0.0081 \\
\hline Large areas of lawn at your property & 0.7537 & -0.0535 & -0.1257 & -0.1259 & 0.0761 \\
\hline A vibrant landscape & 0.6454 & 0.1263 & 0.0223 & 0.2319 & -0.1212 \\
\hline A landscape that adds value to my home & 0.5420 & -0.0100 & -0.0117 & 0.4484 & -0.1620 \\
\hline Large areas of garden beds at your property & 0.5326 & 0.3706 & -0.0866 & -0.1333 & 0.0646 \\
\hline A landscape that fits into the neighborhood & 0.5142 & -0.1194 & 0.0078 & 0.4712 & -0.1388 \\
\hline Working with plants outdoors is a valuable way to spend time & 0.0243 & 0.9252 & 0.0530 & 0.0160 & 0.0007 \\
\hline $\begin{array}{l}\text { Working with plants outdoors is a pleasant break from my } \\
\text { other activities }\end{array}$ & 0.0294 & 0.9231 & 0.0434 & 0.0109 & 0.0021 \\
\hline $\begin{array}{l}\text { I get great satisfaction from working in the outdoor landscaped } \\
\text { areas around my home }\end{array}$ & 0.1278 & 0.8231 & -0.0336 & -0.0447 & 0.0437 \\
\hline $\begin{array}{l}\text { I like to enjoy the harvest from my outdoor vegetables } \\
\text { and herbs }\end{array}$ & -0.0513 & 0.6332 & -0.0812 & 0.0297 & 0.1249 \\
\hline $\begin{array}{l}\text { I like to enjoy the look and feel a nicely landscaped } \\
\text { outdoor area }\end{array}$ & 0.1568 & 0.5010 & -0.0158 & 0.2721 & -0.0834 \\
\hline I do not like working with outdoor plants. & 0.1924 & -0.8278 & 0.0217 & 0.0477 & 0.3579 \\
\hline I hardly ever use the outdoor space at my home for recreation & 0.1124 & 0.0325 & 0.9179 & -0.0081 & 0.1815 \\
\hline I never entertain friends outdoors & 0.0604 & 0.0425 & 0.8526 & -0.0251 & 0.2103 \\
\hline $\begin{array}{l}\text { The outdoor space around my home is an important place } \\
\text { for my leisure activities }\end{array}$ & 0.1879 & 0.1606 & -0.6973 & 0.0106 & 0.1652 \\
\hline My family makes a lot of use of the outdoor space at our home & 0.1629 & 0.0990 & -0.7500 & -0.0090 & 0.1987 \\
\hline A landscape with low maintenance & -0.1229 & -0.0986 & -0.0404 & 0.8663 & 0.0189 \\
\hline A landscape that uses no supplemental irrigation & -0.0521 & 0.0857 & 0.0145 & 0.7297 & 0.1973 \\
\hline A landscape that uses plants with low water requirements & 0.0839 & 0.2480 & 0.0055 & 0.5976 & 0.1475 \\
\hline $\begin{array}{l}\text { In a water crisis, we should not buy or try to maintain outdoor } \\
\text { landscape plants }\end{array}$ & -0.2408 & -0.0147 & 0.0048 & 0.2087 & 0.7398 \\
\hline $\begin{array}{l}\text { I have decreased my outdoor plant purchases due to water } \\
\text { restrictions in my neighborhood }\end{array}$ & 0.1677 & -0.0275 & 0.0984 & -0.0532 & 0.7234 \\
\hline Percent of variance $($ total $=67.1 \%)$ & $21.9 \%$ & $18.3 \%$ & $13.7 \%$ & $8.1 \%$ & $5.1 \%$ \\
\hline Variance explained (before rotation) & 8.4805 & 2.6737 & 1.6311 & 1.3893 & 1.2638 \\
\hline Variance explained (orthogonal rotation) & 4.3570 & 4.2127 & 2.8040 & 2.5451 & 1.5197 \\
\hline $\begin{array}{l}\text { Variance explained eliminating other components } \\
\text { (oblique rotation) }\end{array}$ & 2.6631 & 2.5392 & 1.9873 & 1.8537 & 1.4431 \\
\hline Variance explained ignoring other components (oblique rotation) & 6.5053 & 6.5292 & 4.5158 & 3.8770 & 1.6321 \\
\hline Cronbach coefficient alpha-raw variables & 0.8517 & 0.8563 & 0.8797 & 0.8578 & 0.8640 \\
\hline Cronbach coefficient alpha-standardized variables & 0.8653 & 0.8700 & 0.8927 & 0.8705 & 0.8779 \\
\hline Cronbach coefficient alpha-raw variables (overall) & & & 0.8390 & & \\
\hline Cronbach coefficient alpha-standardized variables (overall) & & & 0.8571 & & \\
\hline
\end{tabular}

${ }^{\mathrm{z}}$ Loadings in bold indicate item component assignments.

${ }^{\mathrm{y}} \mathrm{SAS}$ for Windows, version 9.4, SAS Institute Inc., Cary, NC.

Table 2. Comparison cluster means on four factors related to water conservation (WC): Expertise, Involvement, Importance, and Impact; and five landscape factors: Active Landscape Use and Enjoyment, Passive Landscape Use and Enjoyment, Landscape Pride, Low Water Input Landscape, and Response in Drought (water-sensitive landscape).

\begin{tabular}{|c|c|c|c|c|}
\hline \multirow[b]{4}{*}{ Landscape Components } & \multicolumn{2}{|c|}{ Cluster } & \multirow[b]{4}{*}{$\mathrm{F}^{\mathrm{z}}$} & \multirow[b]{4}{*}{$P^{\mathrm{z}}$} \\
\hline & Active Engagement Landscape Activities & Obligatory Passive Landscape Activities & & \\
\hline & $\mathrm{n}=989$ & $\mathrm{n}=554$ & & \\
\hline & Mean (SE) & Mean (SE) & & \\
\hline Active Landscape Use and Enjoyment & $0.53(0.019)$ & $-0.95(0.036)$ & 1606.508 & 0.001 \\
\hline Passive Landscape Use and No Enjoyment & $-0.50(0.023)$ & $0.89(0.033)$ & 1247.595 & 0.001 \\
\hline Landscape Pride & $0.32(0.028)$ & $-0.56(0.040)$ & 335.719 & 0.001 \\
\hline Low Water Input Landscape & $0.14(0.027)$ & $-0.26(0.051)$ & 59.698 & 0.001 \\
\hline Response in Drought & $0.03(0.034)$ & $-0.05(0.036)$ & 2.410 & 0.121 \\
\hline
\end{tabular}

to discover whether there was an activepassive dimension, as described by Pine and Gilmore (2011), for landscape interactions and understand the implications for horticultural producers and retailers. We identified two groups: Active Engagement cluster and Obligatory Passive cluster. Although not extreme ends of the active-passive continuum described by Pine and Gilmore (2011), these two clusters engage in more (Active cluster) or less (Passive cluster) activity for different motivations. People in the Passive cluster may feel obligated to adhere to a minimum level community identity and social status by maintaining a landscape somewhat similar in appearance; the motivation for the choice may lie in either a lack of knowledge of landscaping and/or lack of funds for landscaping (Harris et al., 2013; Robbins et al., 2001). The Passive cluster had an $18 \%$ lower household income, half the percentage had obtained a bachelor's degree, and had plant expenditures less than half of what the Active cluster had.

For plant producers, wholesalers, and retailers, the knowledge ascertained from this study can be used to market plants more 
Table 3. Comparison of 2015 and 2016 mean plant expenditures and percentage of members making purchases of 12 types of plants for participants in two clusters based on landscape activity.

\begin{tabular}{|c|c|c|c|c|}
\hline \multirow[b]{4}{*}{ Plant-related purchases } & \multicolumn{2}{|c|}{ Cluster } & \multirow[b]{4}{*}{ Test statistic ${ }^{z}$} & \multirow[b]{4}{*}{$P^{\mathrm{z}}$} \\
\hline & \multirow{2}{*}{$\frac{\text { Active Engagement Landscape Activities }}{\mathrm{n}=989}$} & \multirow{2}{*}{$\begin{array}{c}\text { Obligatory Passive Landscape Activities } \\
\mathrm{n}=554 \\
\end{array}$} & & \\
\hline & & & & \\
\hline & Mean (SE) & Mean (SE) & & \\
\hline Spent in 2016 & $\$ 115.23(137.46)$ & $\$ 55.42(93.129)$ & $\mathrm{F}=228.939$ & 0.001 \\
\hline Spent in 2015 & $\$ 157.39(142.55)$ & $\$ 60.02(97.40)$ & $F=202.307$ & 0.001 \\
\hline \multicolumn{5}{|l|}{ Percent buying $(\%)$} \\
\hline Annual flowering plants & 81.4 & 18.6 & $\chi^{2}=204.139$ & 0.001 \\
\hline Vegetable transplants & 87.7 & 9.3 & $\chi^{2}=269.423$ & 0.001 \\
\hline Herbs & 83.0 & 17.0 & $\chi^{2}=103.997$ & 0.001 \\
\hline Perennial plants & 83.8 & 16.2 & $\chi^{2}=110.874$ & 0.001 \\
\hline Flowering shrubs & 87.0 & 13.0 & $\chi^{2}=84.221$ & 0.001 \\
\hline Evergreen shrubs & 87.3 & 12.7 & $\chi^{2}=28.864$ & 0.001 \\
\hline Fruit-producing trees & 91.0 & 9.0 & $\chi^{2}=49.851$ & 0.001 \\
\hline Evergreen trees & 90.7 & 9.3 & $\chi^{2}=35.239$ & 0.001 \\
\hline Shade trees & 87.2 & 12.8 & $\chi^{2}=29.313$ & 0.001 \\
\hline Indoor flowering potted plants & 80.5 & 19.5 & $\chi^{2}=48.993$ & 0.001 \\
\hline Indoor foliage plants & 84.8 & 15.2 & $\chi^{2}=37.593$ & 0.001 \\
\hline Succulents & 83.7 & 16.3 & $\chi^{2}=41.807$ & 0.001 \\
\hline
\end{tabular}

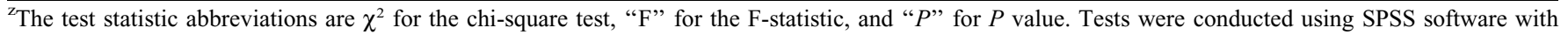
adjustments for unequal variances (SPSS for Windows, version 25; SPSS, Inc., Chicago, IL).

Table 4. Comparison of mean demographic characteristics for members of Active and Passive Landscape clusters.

\begin{tabular}{|c|c|c|c|c|}
\hline \multirow[b]{4}{*}{ Demographic characteristics } & \multicolumn{2}{|c|}{ Cluster } & \multirow[b]{4}{*}{ Test statistic ${ }^{z}$} & \multirow[b]{4}{*}{$P^{\mathrm{z}}$} \\
\hline & Active Engagement Landscape Activities & Obligatory Passive Landscape Activities & & \\
\hline & $\mathrm{n}=989$ & $\mathrm{n}=554$ & & \\
\hline & Mean (SE) & Mean (SE) & & \\
\hline Number of adults & $1.24(0.028)$ & $1.09(0.038)$ & $\mathrm{F}=10.804$ & 0.001 \\
\hline Number of children & $0.58(0.031)$ & $0.17(0.024)$ & $\mathrm{F}=80.005$ & 0.001 \\
\hline Percent Caucasian & 87.16 & 87.55 & $\chi^{2}=3286.043$ & 0.001 \\
\hline Percent Native American & 0.30 & 0.54 & $\chi^{2}=3286.043$ & 0.001 \\
\hline Percent Pacific Islander & 1.21 & 0.54 & $\chi^{2}=7316.334$ & 0.001 \\
\hline Percent Female & 37.0 & 20.0 & $\chi^{2}=1.218$ & 0.001 \\
\hline Age (years) & $55(0.549)$ & $60(0.666)$ & $\mathrm{F}=35.874$ & 0.001 \\
\hline Percent obtained Bachelor's degree & 68.3 & 31.7 & $\chi^{2}=16.415$ & 0.022 \\
\hline
\end{tabular}

${ }^{\mathrm{z}}$ The test statistics abbreviations are $\chi^{2}$ for the chi-square test, " $\mathrm{F}$ " for the F-statistic, and " $P$ " for $P$ value. Degrees of freedom are noted in parenthesis along with the test statistic. Tests were conducted using SPSS software with adjustments for unequal variances (SPSS for Windows, version 25; SPSS, Inc., Chicago, IL).s

effectively to consumers. The Active segment will likely be a better target for messaging about a wide variety of plants and engaging in the landscape in a wider variety of ways. If the Passive group feels landscaping is more of an obligation, it would likely take a significant marketing effort to increase their spending; however, they may be a rich target for services, which would meet their obligation but in a less-engaging manner. Future research might investigate effective marketing messages for this group.

People in the Active segment had positive attitudes of landscape ideals, such as pride in landscape and desire a low water input landscape. These individuals also were younger, more affluent, and a larger percentage of members purchased plants in all plant categories because of their enjoyment in plant activities. This also includes higher purchasing behavior of indoor plants. Although unlikely, because of differences in attitudes, marketing efforts aimed at Active landscape users could potentially appeal to passive landscape users, as well.

Our goal was to better understand consumer attitudes for active vs. passive land- scape enjoyment. We expected to observe multiple clusters but found binary active and obligatory landscape participation, especially in terms of the landscape purchases and water conservation and other plant importance attitudes. We provided evidence to support our hypothesis that homeowners were not homogeneous in their attitudes about landscape activities, as seen with the differences between the two clusters. We also hypothesized that their purchasing behavior and demographical background also would be heterogeneous. Results from this study confirm these hypotheses.

Findings can be readily incorporated into marketing messages to better connect with consumers who have diverse, if not opposite, motivations for purchasing and enjoying horticultural plants. For example, retail employees and landscape professionals might initially ask about activity level desired in the landscape as an initial screening question. Subsequent conversation and questions could then be tailored toward the desired activity level and related purchases. For an active consumer, messages could focus on the de- sire for diverse plant types in their landscape or capitalize on the fact that they find immense pride in their landscape and find water conservation important. With the Active Engagement cluster comprising a more diverse population, messages should represent the wide breadth of individuals purchasing plants and enjoying their landscape. Such messages would be instrumental in positively influencing the value proposition (and thereby elasticity of demand) for ornamental plants, affecting likelihood of purchase as well as willingness to pay (Hall and Dickson, 2011). More passive consumers might be more interested in services and may benefit from messages regarding the multitude of plant benefits.

\section{Literature Cited}

Abell, D.F. 2010. Managing with dual strategies: Mastering the present preempting the future. Free Press, Simon and Schuster.

Abraham, A., K. Sommerhalder, and T. Abel. 2010. Landscape and well-being: A scoping study on the health-promoting impact of outdoor environments. Intl. J. Public Health 55(1):59-69. 
Barton, S.S. and B.K. Behe. 2017. Retail promotion and advertising in the green industry: An overview and exploration of the use of digital advertising. HortTechnology 27:99-107.

Beard, J.B. and R.L. Green. 1994. The role of turfgrasses in environmental protection and their benefits to humans. J. Environ. Qual. 23(3):452-460.

Beck, T., J. Heimlich, and M. Quigley. 2002. Gardeners perceptions of the aesthetics, manageability, and sustainability of residential landscapes. Appl. Environ. Educ. Commun. 1(3):163-172.

Behe, B.K., M. Bae, P.T. Huddleston, and L. Sage. 2015. The effect of involvement on visual attention and product choice. J. Retailing Consum. Serv. 24:10-21.

Behe, B., B. Campbell, J. Dennis, C. Hall, R. Lopez, and C. Yue. 2010. Gardening consumer segments vary in eco-practices. HortScience 45:1475-1479.

Behe, B.K., B.L. Campbell, C.R. Hall, H. Khachatryan, J.H. Dennis, and C. Yue. 2013. Consumer preferences for local and sustainable plant production characteristics. HortScience 48:209215.

Behe, B.K., P.T. Huddleston, and L. Sage. 2016. Age cohort influences brand recognition, awareness, and likelihood to buy vegetable and herb transplants. HortScience 51:145-151.

Behe, B., M. Knuth, C.R. Hall, P.T. Huddleston, and R.T. Fernandez. 2018. Consumer involvement with and expertise in water conservation and plants affect landscape plant purchases, importance, and enjoyment. HortScience 53:1164 1171.

Bhatti, M. and A. Church. 2001. Cultivating natures: Homes and gardens in late modernity. Sociology 35(2):365-383.

Blaine, T.W., S. Clayton, P. Robbins, and P.S. Grewal. 2012. Homeowner attitudes and practices towards residential landscape management in Ohio, USA. Environ. Mgt. 50(2):257271.

Boone, C.G., M.L. Cadenasso, J.M. Grove, K. Schwarz, and G.L. Buckley. 2010. Landscape, vegetation characteristics, and group identity in an urban and suburban watershed: Why the $60 \mathrm{~s}$ matter. Urban Ecosyst. 13(3):255-271.

Chau, C.K., M.S. Tse, and K.Y. Chung. 2010. A choice experiment to estimate the effect of green experience on preferences and willingnessto-pay for green building attributes. Build. Environ. 45(11):2553-2561.

Clayton, S. 2007. Domesticated nature: Motivations for gardening and perceptions of environmental impact. J. Environ. Psychol. 27(3): 215-224.

Cobanoglu, C., B. Warde, and P.J. Moreo. 2001. A comparison of mail, fax and web-survey methods. Intl. J. Mktg. Res. 43(4):441-452.

Cohen, P. and I. Baldwin. 2018. National Gardening Survey. 8 Sept. 2018. <GardenResearch.com>.

Colding, J. 2007. 'Ecological land-use complementation' for building resilience in urban ecosystems. Landsc. Urban Plan. 81(1-2):4655.

Crow, T., T. Brown, and R. De Young. 2006. The Riverside and berwyn experience: Contrasts in landscape structure, perceptions of the urban landscape, and their effects on people. Landsc. Urban Plan. 75(3-4):282-299.

Daniels, G.D. and J.B. Kirkpatrick. 2006. Comparing the characteristics of front and back do- mestic gardens in Hobart, Tasmania, Australia Landsc. Urban Plan. 78(4):344-352.

Dennis, M. and P. James. 2016. User participation in urban green commons: Exploring the links between access, voluntarism, biodiversity and well being. Urban For. Urban Green. 15:22-31.

Dillman, D., J. Smyth, and L. Christian. 2009. Internet, mail, and mixed-mode surveys: The tailored design method. John Wiley \& Sons, Inc., Hoboken, NJ.

Elmqvist, T., J. Colding, S. Barthel, S. Borgström, A. Duit, J. Lundberg, and J. Bengtsson. 2004 The dynamics of social-ecological systems in urban landscapes: Stockholm and the national urban park, Sweden. Ann. N. Y. Acad. Sci. 1023(1):308-322.

Goddard, M.A., A.J. Dougill, and T.G. Benton. 2010. Scaling up from gardens: Biodiversity conservation in urban environments. Trends Ecol. Evol. 25(2):90-98.

Goddard, M.A., A.J. Dougill, and T.G. Benton. 2013. Why garden for wildlife? Social and ecological drivers, motivations and barriers for biodiversity management in residential landscapes. Ecol. Econ. 86:258-273.

Grove, J.M., A.R. Troy, J.P.M. O’Neil-Dunne, W.R. Burch, M.L. Cadenasso, and S.T.A Pickett. 2006. Characterization of households and its implications for the vegetation of urban ecosystems. Ecosystems 9(4):578-597.

Hall, T. 2010. Goodbye to the backyard? The minimization of private open space in the Australian outer-suburban estate. Urban Policy Res. 28(4):411-433.

Hall, C.R. and M. Dickson. 2011. Economic, environmental, and health and well-being benefits associated with green industry products and services: A review. J. Environ. Hort 29(2):96-103

Hall, C.R., J.J. Haydu, and A.W. Hodges. 2005. Economic impacts of the green industry in the United States: Final report to the National Urban and Community Forestry Advisory Committee. University of Tennessee, Extension Service.

Hardy, J., B. Behe, S. Barton, T. Page, R.E. Schtuzki, K. Muzi, R.T. Fernandez, M.T. Haque, J. Brooker, C.R. Hall, R. Hinson, P. Knight, R. McNiel, D.B. Rowe, and C. Safley. 2000. Consumer perceptions of landscape plant size, design style, and material. J. Environ. Hort 18(4):224-230.

Harris, E.M., D.G. Martin, C. Polsky, L. Denhardt, and A. Nehring. 2013. Beyond "lawn people": The role of emotions in suburban yard management practices. Prof. Geogr. 65(2):345361 .

Kirkpatrick, J.B., G.D. Daniels, and T. Zagorski. 2007. Explaining variation in front gardens between suburbs of Hobart, Tasmania, Australia. Landsc. Urban Plan. 79(3-4):314-322.

Kirkpatrick, J.B., A. Davison, and G.D. Daniels. 2012. Resident attitudes towards trees influence the planting and removal of different types of trees in eastern Australian cities. Landsc. Urban Plan. 107(2):147-158.

Knuth, M., B.K. Behe, C.R. Hall, R.T. Fernandez, and P.T. Huddleston. 2018. Consumer perceptions, attitudes, and purchase behavior with landscape plants during real and perceived drought periods. HortScience 53:49-54.

Kweon, B.S., C.D. Ellis, P.I. Leiva, and G.O Rogers. 2010. Landscape components, land use, and neighborhood satisfaction. Environ. Plann. B Plann. Des. 37(3):500-517.
Larsen, L. and S.L. Harlan. 2006. Desert dreamscapes: Residential landscape preference and behavior. Landsc. Urban Plan. 78(1-2):85100 .

Lawless, H. and H. Heymann. 2010. Data relationships and multivariate application. In: Sensory evaluation of food. Food Science Text Series. Springer, New York, NY.

Lin, B.B., K.J. Gaston, R.A. Fuller, D. Wu, R. Bush, and D.F. Shanahan. 2017. How green is your garden? Urban form and sociodemographic factors influence yard vegetation, visitation, and ecosystem service benefits. Landsc. Urban Plan. 157:239-246.

Loram, A., P.H. Warren, and K.J. Gaston. 2008. Urban domestic gardens (XIV): the characteristics of gardens in five cities. Environ. Mgt. 42(3):361-376.

Marco, A., T. Dutoit, M. Deschamps-Cottin, J.F. Mauffrey, M. Vennetier, and V. BertaudièreMontes. 2008. Gardens in urbanizing rural areas reveal an unexpected floral diversity related to housing density. C. R. Biol. 331(6):452-465.

Mathieu, R., C. Freeman, and J. Aryal. 2007. Mapping private gardens in urban areas using object-oriented techniques and very high-resolution satellite imagery. Landsc. Urban Plan. 81(3):179 192.

Matsuoka, R.H. and R. Kaplan. 2008. People needs in the urban landscape: Analysis of landscape and urban planning contributions. Landsc. Urban Plan. 84(1):7-19.

McCullough, D. 1998. Web-based market research: The dawning of a new age. Direct Mktg. 61(9):36-38.

Mennis, J. 2006. Socioeconomic-vegetation relationships in urban, residential land. Photogramm. Eng. Remote Sensing 72(8):911-921.

Nassauer, J., W. Zhifang, and E. Dayrell. 2009. What will the neighbors think? Cultural norms and ecological design. Landsc. Urban Plan. 92:282-292.

Nelson, K.C., M.C. Monroe, and J.F. Johnson. 2005. The look of the land: Homeowner landscape management and wildfire preparedness in Minnesota and Florida. Soc. Nat. Res. 18(4):321-336.

Nowak, D.J., R.A. Rowntree, E.G. McPherson, S.M. Sisinni, E.R. Kerkmann, and J.C. Stevens. 1996. Measuring and analyzing urban tree cover. Landsc. Urban Plan. 36(1):49-57.

Pine, J.P. and J.H. Gilmore. 2011. The experience economy: Updated. Harvard Business Rev. Press, Boston, MA.

Robbins, P., A. Polderman, and T. Birkenholtz. 2001. Lawns and toxins: An ecology of the city. Cities 18(6):369-380.

Syme, G.J., Q. Shao, M. Po, and E. Campbell. 2004. Predicting and understanding home garden water use. Landsc. Urban Plan. 68:121128.

U.S. Census Bureau. 2017. American FactFinder. U.S. Dept. of Commerce. 8 Feb. 2017. <https:// factfinder.census.gov/faces/tableservices/jsf/ pages/productview.xhtml?pid=ACS_15_5YR_ DP05\&src $=p t>$.

Zheng, B., Y. Zhang, and J. Chen. 2011. Preference to home landscape: Wildness or neatness? Landsc. Urban Plan. 99:1-8.

Zhu, Z., B. Behe, P. Huddleston, and L. Sage. 2017. How do pricing and the representation of price affect consumer evaluation of nursery products? A conjoint analysis. Intl. Food Agribus. Mgt. Rev. 20(4):477-492. 